Електронне наукове фахове видання "Ефективна економіка" включено до переліку наукових фахових видань України з питань економіки

(Категорія «Б», Наказ Міністерства освіти і науки України від 11.07.2019 № 975) www.economy.nayka.com.ua | № 2, 2022 | 24.02.2022 p.

DOI: $\underline{10.32702 / 2307-2105-2022.2 .9}$

UDC 336.132.1

V. Druzhynina

Doctor of Economics Sciences, Professor,

Professor of the Department of Business Administration, Marketing and Tourism,

Kremenchuk Mykhailo Ostrohradskyi National University

ORCID ID: 0000-0001-8776-1408

G. Likhonosova

Doctor of Economics Sciences, Professor,

Professor of the Department of Finance, Accounting and Taxation,

National Aerospace University "Kharkiv Aviation Institute"

ORCID ID: 0000-0001-6552-8920

V. Nozhenko

PhD in Technical Sciences, Senior lecturer of the Department of Electrical Engineering, Kremenchuk Mykhailo Ostrohradskyi National University

ORCID ID: 0000-0003-0126-6970

G. Lutsenko

Teacher-methodologist of the highest category of the cycle commission of economics and management, Kharkiv National University of Internal Affairs Kremenchuk flight college

ORCID ID: 0000-0002-2628-5521

\title{
INTERDEPENDENCE INNOVATIVE EDUCATIONAL FORMS UNIVERSITIES AND NATIONAL FINANCIAL SECURITY INSTRUMENTS
}

В. В. Дружиніна,

д. е. н., професор, професор кафедри бізнес адміністрування, маркетингу і туризму,

Кременчуцький національний університет імені Михайла Остроградського

Г. С. Ліхоносова,

д. е. н., професор, професор кафедри фінансів, обліку і оподаткування,

Національний аерокосмічний університет ім. М.С. Жуковського

«Харківський авіачійний інститут»

В. Ю. Ноженко

к. т. н., старший викладач кафедри електротехніки,

Кременчуцьький національний університет імені Михайла Остроградського

Г. П. Луиенко,

викладач-методист вищої категорї циклової комісії економіки та управління,

Кременчуцький льотний коледж Харківського начіонального університету внутрішніх справ

\section{ВЗАЕМОЗАЛЕЖНІСТЬ ІННОВАЦИЙНИХ ФОРМ НАВЧАННЯ В УНІВЕРСИТЕТАХ ТА ІНСТРУМЕНТІВ НАЦІОНАЛЬНОЇ ФІНАНСОВОЇ БЕЗПЕКИ}

The article analyzes the main features of innovative educational forms and methods of working with applicants for higher education. The authors analyze the key features of traditional methods, 
focusing on the most important educational method - the method of project management, translating it into the plane of start-up management. This article addresses issues related to the analysis of start-up project management methodologies. The work focuses on the relationship between the introduction of innovative forms of learning and ensuring financial security and social stability of society. In this aspect the influence of education on economic growth, development of human potential, increase of labour productivity, growth of well-being of the population is considered. The authors identify the channels of positive impact of education on scientific, technical and technological progress, expansion and innovative development of social production, improving the welfare of the population. The authors conclude that there is evidence of a close relationship between education and financial and economic security, as scientific knowledge increases the competence and ability of man, state and society to resist various threats, anticipate and suppress emerging dangers. The authors emphasize the focus of modern education, namely the possibility of forming different professional trajectories through consulting and corporate finance. Particular attention is paid to the need to focus educators on the growth of demand for competencies aimed at data analysis, both in the financial and non-financial spheres. It is obvious that education and the financial and economic sphere have a direct correlation, which is not always noticeable and, as a consequence, is not taken into account when making managerial decisions. However, the links between education and the country's financial and economic performance are less clear and still need to be validated and explored from a practical point of view. These are necessary steps to have a clear idea of what a national education system should be, which ensures the economic, scientific, technical, social and cultural development of the country at the level of unconditional provision of its national security and socio-economic stability.

У статті аналізуються основні особливості інновачійних освітніх форм та методів роботи із здобувачами вищої освіти. Автори аналізують ключові особливості традиційних методів, акцентуючи увагу на найважливімому освітньому методі - методі управління проектами, переводячи його в площину стартап-менеджменту. У иій статті розглядається питання, пов'язане з аналізом методологій управління стартап-проектами. Акиент у роботі зроблений на взаємозв'язку між впровадженням інновачійних форм навчання та забезпеченням фінансової безпеки та соціальної стабільності суспільства. У изьому аспекті розглядається вплив освіти на економічне зростання, розвиток людського потенціалу, підвищення продуктивності праці, зростання добробуту населення. Авторами визначено канали позитивного впливу освіти на науково-технічний $і$ технічний прогрес, розширення та інноваційний розвиток суспільного виробництва, підвищення добробуту населення. Автори приходять до висновку, щз існує доказова база тісного взаємозв'язку освіти та фінансовоекономічної безпеки, оскільки наукове знання підвищує компетентності та здатність людини, держави, суспільства протистояти різним загрозам, передбачати та придушувати виникаючі небезпеки. Автори наголошують на напрямах фокусачії сучасної освіти, а саме можливості формування різних професійних траєкторіях через консалтинг та корпоративні фінанси. Окрема увага присвячена необхідності концентрації уваги освітян на зростанні попиту саме на компетентностях, які спрямовані на аналіз даних, як у фінансових, i нефінансових сферах. Очевидно, щзо освіта і фінансово-економічна сфера мають пряму кореляцію, яка не завжди помітна $i$, як наслідок, не враховується при прийнятті управлінських рішень. Проте наразі не настільки очевидні зв'язки між освітою та фінансово-економічною результативністю країни, які ще потрібно валідузувати та досліджувати саме з практичної точки зору. Це є необхідними кроками для того, щоб мати чітке уявлення про те, якою має бути національна система освіти, яка забезпечує економічний, науково-технічний, сочіальний $і$ культурний розвиток країни на рівні безумовного забезпечення ї̈ начіональної безпеки та соціально-економічної стабільності.

Keywords: innovative educational forms; universities; financial security instruments; economic growth; stability. 


\section{Ключові слова: інновачійні освітні форми; університети; інструменти фінансового забезпечення; економічного зростання; стабільність.}

Formulation of the problem. The educational reform has led to profound changes in the curriculum. It was unambiguously preferable to abandon the encyclopaedic model of acquiring knowledge in favour of activating students to creative activity. This is at the heart of the new curriculum. Other factors - social and psychological contributed to the crisis of the methods used in education today. Until now, the traditional teaching methods used have been based on the teacher as the only source of knowledge or on teamwork. Most often these were: informational lecture, description, story.

Currently, in accordance with the new curriculum, the role of the teacher in the educational process is changing. From the position of a teacher, he becomes an organizer, coordinator and coach of students' work, introducing them to creative activity. In this process, traditional methods are no longer sufficient. Preparing a young person for life in a society filled with information and consumption is a difficult task that requires an active attitude from both the teacher and the student. The most important thing in the learning process and decisive for the success of the methods used is effective communication between the student and the teacher.

Analysis of recent researches and publications. In the last decade, the issue of economic and financial security has become very important in Ukraine. This is evidenced by the attention of scientists to the problem, a significant number of studies on this issue [1, p. 57; 2, p. 2053].

In these works, a wide range of problems of economic security in the spheres of production, distribution and consumption in the regional aspect is investigated.

However, despite the multifaceted nature of the research and the importance of the obtained constructive results, some problems of financial security remain unexplored to date, which highlights the need for in-depth study. Such problems, in particular, include the identification and study of the role and mechanisms of the impact of education on financial security in the country, industries, regions, individual industrial and social facilities.

The thesis that education plays an important role in ensuring the economic, financial and, consequently, national security of the country, is now generally accepted. However, the mechanisms of the positive impact of education on the economic development of society and its socio-economic stability to date remain poorly understood.

The purpose of the article is to analyse the most popular innovative educational methods and forms of education in higher educational institutions, to identify the degree of their impact on the level of financial security, impact on the productive potential and social stability of the country.

Results. In Ukrainian didactics, methods are usually divided into three groups: verbal, visual and practical. According to research, the most in-demand methods for the formation of a modern communicative student are those that are classified as practical. Verbal and observation methods enrich students' knowledge. In practical methods, the application of knowledge comes to the fore. This method is intended not only to recreate the acquired knowledge, but, above all, to expand it and acquire new ones. The weakness of this traditional classification of methods is that it does not include methods that have become a permanent part of the didactic textbook repertoire - they are active methods, the assumption of which is to involve students in the didactic process. The use of active methods has a positive effect not only on the student (knowledge and skills acquired on their own are more durable), but also on the teacher, putting him in the role of a researcher and creator [3]. The essence of active methods is the advantage of teaching over teaching.

Learning for students is the use of active methods that lead to constant changes in thinking and action in order to gain new experiences.

Teaching from a teacher's perspective is the use of activation methods that rely on the interaction of the mentor (teacher) and the student in order to bring about changes in the student.

Student-centred methods provide a higher and better quality of learning than methods that are not inspiring or have little effect. The choice of teaching method depends on the objectives of the classes, the age of the student, the level of his knowledge and educational base. According to Fundacja im. Stefan Batory shows that the method largely determines the amount of knowledge gained. The use of active methods in university practice leads to:

- increasing the effectiveness of teaching and learning;

- opportunities to motivate students to take action;

- opportunities for the development of creative thinking, student and own creativity, the integration of knowledge in various subjects;

- the ability to cooperate and communicate in a group;

- the ability to organize one's own work and the work of others.

\section{Identification of innovative teaching methods.}

Increasingly, teachers come to the conclusion that students trained in administration methods have a certain amount of knowledge, but cannot use it in problem situations [4, p. 34]. For a teenager to be able to solve problems, it is necessary to provide him with the opportunity to gain knowledge in the process of independent research. This is the chance that activation methods offer. Activation of students is all the actions of teachers and students that ensure 
the active participation of students in the implementation of educational and educational tasks. Activation in teaching and upbringing is such an organization of teaching and upbringing that causes the spontaneous involvement of students, arouses and maintains their interest and activity, promotes their clear cooperation with tutor teachers and, as a result, causes their real contribution to the implementation of the outlined didactic tasks and educational plans. Thus, the activating method can be understood as the collective work of the group and the teacher, which serves learning through experience.

Activating teaching methods has many benefits:

- active participation in the classroom of students and teachers;

- the ability to personify knowledge, create opportunities for their achievement through their own intellectual activity;

- activation of the resources of the acquired knowledge, necessary for obtaining new information;

- activating and developing the skills needed to solve problems;

- evoking an emotional attitude to what is being done;

- creating a field for interaction between all participants in pedagogical practice;

- creating an opportunity for your own research and discoveries;

- performing a diagnostic role through feedback from student to teacher about opportunities and interests;

- the emergence of the opportunity to know yourself and others;

- the ability to team up and show empathy, preparation for self-study and improvement; more attractive.

- developing collaborative learning methods, taking into account different learning styles that make classes

Active (activating) teaching methods are group work techniques that especially stimulate student activity. They facilitate the learning process, making learning more varied, and therefore more enjoyable and easy; enliven the atmosphere in the classroom, often giving unexpected results when working with weak students. Students accustomed to gaining knowledge and skills through active methods are more independent, more critical, easier to formulate judgments and opinions, and more willingly and boldly take part in public speaking. Some of these techniques require special training from the instructor, but the results are worth it.

The most common active learning methods include: analysis of the decision-making process using a decision tree; brainstorm; marketing discussion; debates (analysis of arguments "for and against"); educational games; elements of the drama (intervening roles); work in small groups; simulators; topical research; obtaining and evaluating different points of view; verbal tennis.

When familiarizing with the methods that activate students, one should remember about the psychological foundations of student preferences and perception, concentration and distraction, activation and silence [5;6].

It should be kept in mind that the average memorization ability of students depends on the method used (Figure 1).

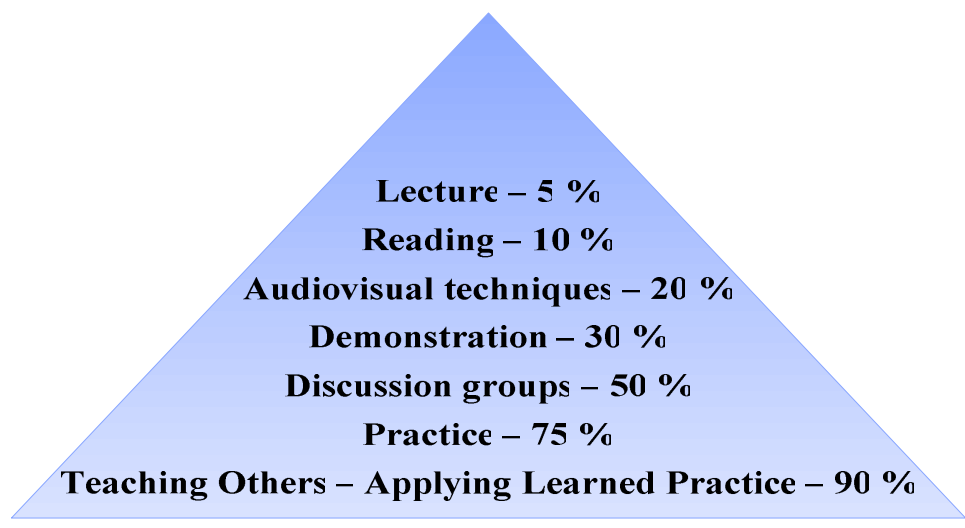

Fig. 1. Pyramid memorization methods by students

Source: created by the authors

Good results are achieved due to the fact that traditional teaching methods become more attractive with elements that require visual perception, for example, a lecture should be documented using diagrams, presentations and other visual aids. Especially when it comes to distance learning, which has become very relevant in the context of the global COVID 19 pandemic. Due to this problem faced by Ukrainian education, virtual laboratory complexes (VLC) are relevant, the purpose of which is to develop two areas: distance learning using computer telecommunications and ensuring an increase in the level of scientific and professional competencies of students of all educational levels - bachelors, masters., doctors of philosophy. It should be noted that VLC have both social and economic advantages over traditional laboratory stands (Table 1) [7, p. 121].

The results of table 1 demonstrate the advantages of VLC over classical ones, and first of all, the decisive advantage is the low cost of VLC over classical ones, regardless of the size of the group [8, p. 28; 9, p. 15]. 
Table 1. Comparison of indicators of types of laboratory stands

\begin{tabular}{ccc}
\hline Indicators & \multicolumn{2}{c}{ Laboratory stands / workshops } \\
\cline { 2 - 3 } & Classic & Virtual \\
\hline Development cost, thousand UAH & $50-300$ & Up to 25 \\
\hline Update and modernization ability & no & yes \\
\hline Energy intensity & yes & no \\
\hline Repair and service & yes & yes \\
\hline Classical form of study & yes & yes \\
\hline Distance learning & no &
\end{tabular}

\section{Reduction of labour various types to a unit of the utility measurement.}

Some scientists [10, p. 49] use the method of labour reduction, bringing its various types (complex and simple, skilled and unskilled, mental and physical) to a common unit, which can be taken as a starting point when building a system of coefficients of labour complexity. In order to be able to quantify the differences in economic returns from the work of workers with different levels of education, wage rates of employees in the industry are used, and the starting unit is the size of wages of uneducated unskilled workers.

The method of reduction can be used as an opportunity to study the phenomenon of the impact of education on productivity and the resulting economic growth, which in their unity are the determining factors of economic security.

However, despite all efforts, it has not yet been possible to obtain convincing results in this area. In fact, it has only become obvious that the current methodological framework does not allow to calculate the reduction coefficients with acceptable accuracy.

A common disadvantage of all methods of calculating the effectiveness of education based on labour reduction is that they are all based on the use of indicators that are very conditionally related to the quality parameters of the work of workers. For example, the relationship between the cost of training and the number of years of training of employees, on the one hand, and the productivity of these employees, on the other hand, is not traceable at all.

Scientists from Great Britain [11, p. 14] managed to give a fairly complete and realistic picture of causal relationships that mediate the impact of education (quality of human, human resources) on production. The researchers did not limit themselves to considering the self-evident dependence of labour productivity on the level of qualification of the employee, but also identified and studied some more indirect relationships that have indisputable economic significance.

Scientists continue to $[2$, p. $2052 ; 11$, p. $15 ; 12$, p. 358] expand the range of analysed factors influencing education on economic growth, financial security, try to develop representative, suitable for practical application of methods for calculating the economic efficiency of education and assessing the impact of educational level on economic and financial security.

Thus, financial and economic science is primarily faced with the task of further development of the theory of financial and economic security, in which, in our opinion, and should work to study funding, in relation to the broader task - the socio-economic efficiency of education.

From the identification and analysis of causal links that connect education with various spheres of society, the state of economic and social security, sustainability can begin the development of theoretical provisions for establishing the parameters of education development requirements for economic security and tools needed for monitoring, diagnosing and monitoring the situation in the future.

Undoubtedly, the main element that ensures the economic security of any country is its human resources not only in quantitative but also, above all, in qualitative terms. And here education plays a key role, participating in the formation of labour potential and, thus, influencing such factors of social development as scientific and technological progress, expansion and innovative development of social production, improving the welfare of the population. This influence is carried out from many directions.

Thus, providing a solid foundation for the development of science, education thus not only contributes to the development of production, but also creates conditions for changing the structure of the economy, increasing the share of knowledge-intensive industries. The level of scientific and technical, innovative, technological potential of the economy, the degree of progressiveness of production are largely determined by the educational potential of employees, the number of educated people, the quality of knowledge acquired and added in practice, the structure of specialties, the degree of demand for labour. It is for this reason that the modern economy is called the knowledge economy [12, p. 362].

\section{Advantages and Disadvantages of Implementing Innovative Teaching Methods.}

The use of VLC in the training process allows you to prepare and retrain specialists who meet modern requirements and are able to professionally take part in the design, configuration and operation of modern systems and technological processes in completely different areas of training, including in air navigation when training pilots. Pilot training systems in virtual reality have great potential to make professional flight training more accessible. The basics of flight are taught using a smartphone and a mobile VR headset. This method of pilot training has gained traction overseas, especially the Air Force is using this technology as part of their training systems, and it has had 
positive results with people suffering from PTSD. However, aviation simulators are still relevant in the national pilot training system, which allow future pilots in the learning process to interact with a real cockpit of an aircraft or helicopter, to work out emergency situations using the example of real aviation accidents, to simulate any unfavourable meteorological phenomena, which is especially valuable when counting on climatic conditions of aircraft operation. And the introduction of simulators into the educational process can significantly reduce the cost of training.

The effectiveness of teaching by activating methods is determined not only by the subject training of the teacher, his character traits, but also the contacts he has with his students. The effectiveness of the methods is also influenced by who the teacher works with, that is, the predispositions and individual characteristics of students. The essence of these methods is to maximally attract the attention of students to the material that is given to them in the classroom, to involve students in the discussion, and if the academic discipline is based on the processing of statistical information, then these methods should develop students' abilities in collecting, processing and analysing the current situation and, on the basis of the analysis carried out, propose a number of effective measures for the problem situation. This way of conducting classes represents the teacher already as a teacher-trainer, whose main competencies are innovation, motivation, punctuality, flexibility, consistency, creativity, teaching skills, erudition, rationality, etc. The main feature of the classes is the optimal balance of theory and practice. As you know, the student's brain perceives and memorizes information for 15-20 minutes, respectively, the remaining time is devoted to practice. Therefore, in his classes, the teacher usually gives out 30-35\% of the theory, and the rest $65-70 \%$ of the practice, as a result, the lecture is carried out in the form of a lecture-conversation with elements of discussion, exchange of views, brainstorming. A mixed type of teaching is widely used to conduct classes with "Teaching Informatics".

To assimilate more voluminous material and if the group is large, then it is effective to divide it into several subgroups, for example, 5 people in a subgroup, and continue to consider the material, for example, on the reasons for unemployment and labour migration of the population when describing the discipline "Personnel management at tourism enterprises", functions and the importance of tourism for the economy of the state in the study of the discipline "Economics of recreation and tourism." The main advantage of this method is that students can share their own experience gained during internships or from existing work experience, have the opportunity to integrate the accumulated knowledge from other disciplines into this educational component. In addition, students show their creativity, initiative, communication skills, team spirit and independent thinking are formed.

Another innovative teaching method is the project method, which can be applied in the presentation of both disciplines of an economic nature and in the presentation of technical disciplines. If we talk about the discipline "Organization of the hotel and restaurant industry", then, depending on the research base, students prepare a project for the organization of services in the institutions of the hotel and restaurant industry according to a previously agreed plan and, based on the results of their research, prepare a presentation and test the results of their research in front of their classmates.

The project method primarily teaches students to speak in front of an audience, thereby developing oratory and the ability to integrate knowledge and teachings from various fields of science, technology and technology, creative industries, for example, for table setting in a restaurant.

The use of the project method in the study of the discipline "Organization of excursion activities" makes it possible to develop new excursion routes, primarily in the city where students live, for example, in the city of Kremenchuk, clearly regulating the time and distance of this route, as well as excursions to some cities of Ukraine Poltava, Lviv, Kiev. Testing of the newly developed excursions is carried out for junior students, however, recently such excursions have been presented by students who speak a foreign language for a foreign delegation that took part in an international conference held at the university.

The project method is quite popular when presenting educational material in technical specialties. So, when studying the discipline "Energy audit", the use of the project method allows students to develop recommendations for the rational use of fuel and energy resources (FER) and draw up a plan of organizational and technical measures to save fuel and energy at the enterprise [13, p. 49]. Also, when drawing up the fuel and energy balances of an enterprise, it is advisable to use diagrams, graphs, tables, which will allow students, due to visual perception, to more easily assess the actual state of the efficiency of the use of fuel and energy resources at the enterprise, identify the causes of losses of fuel and energy resources and determine their value.

In addition, since last year, the educational component "Management of start-up projects" has been introduced into the educational process for master students of the educational program "Cyber-physical systems and smart technologies", which will ensure the achievement of programmatic learning outcomes based on an innovative approach to solving business problems. will further increase the competitiveness of any company. A certain management methodology is necessary for start-up executors to achieve the set results and translate the idea into reality. The study of such an innovative discipline in the curriculum is based on one of the main characteristics of start-ups' - functioning in conditions of uncertainty, this characteristic determines the main of the key features of project management - the need to constantly combat uncertainty $(14$, p. $65 ; 15$, p. 147]. One of the most effective ways to get uncertain is to get constant feedback or even involve the consumer in the process of shaping and testing a business model. In connection with the development of individual start-up projects, students of the IT industry apply both traditional and flexible approaches and methods of project management in the IT industry, which are presented in Table 2. 
Traditional methodologies, considered the classic approach to project management, have well-defined work procedures for planning and implementing a project. They are characterized by a predetermined fixed plan, budget and properly allocated resources. In this case, the scale of the project cannot be changed. Agile methodologies work very differently. With the dynamically changing requirements of the recipient, changes in the scope of the project occur, and the entire structure of the organization of labour has a completely different dimension. It should also be noted that IT enterprises often use their own customized project management systems that have been developed based on different methodologies and previous experience in developing new products.

Table 2. Approaches to project management in it companies

\begin{tabular}{cc}
\hline \multicolumn{2}{c}{ Enterprise project management approaches } \\
\hline Traditional & Flexible \\
\hline StandardPMBOK®Guide & AgilePM®[DSDMAtern] methodology \\
PRINCE2 methodology & Scrum [Scrum.org] methodology \\
IPMA® approach & Scrumban [CoreyLadas] methodology \\
& Methodology ExtremeProgramming \\
[Extremeprogramming.org] \\
CrystalClear methodology [Alistair Cockburn] \\
\hline Hybrydowa PRINCE2 methodology \\
\hline
\end{tabular}

The application of these approaches and methodology enables future professionals to create and implement projects aimed at the needs of society, but so far throughout the academic year, master's degree seekers have worked on projects related to the development of a web-based vehicle rental system in order to improve the economic, physical and environmental spheres of human activity, as well as on the creation of an on-line job search platform / employees without appropriate qualifications with its further development.

In addition, when describing the academic disciplines "Organization of a hotel and restaurant economy", "Management of start-up projects", etc. to visualize the proposed material in teaching, another innovative method is used - feature and documentary thematic films, which allows students to better remember the material, develop critical thinking through the prism of their own opinions and statements, and the ability to argue their own point of view [12, p. $350]$.

Also we would like to note that in the process of teaching the discipline "Fundamentals of Scientific Research", which is read to first-year students from this academic year, decided to introduce another innovative method - "living library", the peculiarity of the implementation of this method is that books are living people (in our case, these are senior students, usually fourth-year students and masters), and the reading process is replaced by a conversation. In the process of "reading", senior students who are engaged in scientific research, test the results of their research at conferences and in specialized journals, win prizes in competitions of student research papers, share their experiences and sincerely answer questions asked.

The result of any lesson is feedback. Feedback can be completely different depending on the number of students in the group. If the group is large, then it can be divided into three subgroups. One of the options for the division is students by interests in relation to tourism activities. For example, three volunteers are selected, and then each of the volunteers chooses his team according to the questions posed: "Who will you take on a hike?", "Who would you entrust to carry a backpack?", "Who would you share your secret with?" Each of these groups should creatively formulate answers to the questions posed: "What was discussed in the lesson?", "What information can be used in real life?", "What obstacles arise in the perception of information and how to overcome them?" And upon completion of the study of the discipline "Management of start-up projects" as feedback, they presented their start-ups, which were associated with the development of a web-based vehicle rental system in order to improve the economic, physical and environmental spheres of human activity, and the creation of an online job search platform / employers without appropriate qualifications, but with its further development. All of the above provides students-team members with experience and confidence in the preparation of a finished product, and most importantly, acquire soft skills, which are currently archival and worth developing.

Therefore, the educational process requires the introduction of strategies that are optimal for effective learning, which consist of: the use of activating methods, group work and verification of the knowledge and skills acquired with the ability to use various sources of information. Examples of topics implemented using activation methods in education for sustainable development can be as follows: Thus, using the decision tree method, you can answer the questions: How to reduce the harmful effects of waste, such as vehicles, on the environment? Can artificial fertilizers be used? Where can I get electricity? Is it worth developing large-scale agriculture? - How to protect biodiversity in Ukraine? Should you continue to use non-renewable energy sources? Is it worth developing alternative energy? the "SWOT" method - an increase in the area of protected areas, genetically modified food, an increase in the area of protected areas, the use of plant protection chemicals, the use of biofuels, traditional / organic farming, the exploitation of forest resources; method 635 - Causes of environmental degradation; the impact of intensive exploitation of natural resources, how to protect the forest? 


\section{Causal relationships of a decrease in the level of labour productivity.}

Currently, industrialized countries pay special attention to the development of information technology, improvement of methods of obtaining, storing, searching, transmitting information. And here education not only contributes to the development of these technologies through science, but also directly forms in students the ability to find and use the necessary sources of information. Under the influence of new information technologies, the educational process is also transforming. All this, of course, is important to ensure information and, consequently, financial security of the country in modern conditions.

Participating in the formation of the qualification level of workers, education has a significant impact on such factors of production as productivity, innovation receptivity, improvement of means and methods of production directly in production (innovation), economical use of resources, reducing production losses.

Low labour productivity in most sectors and areas of the economy, which has been observed for a long time, poses the greatest, significant danger to it, negatively affects ratings and economic relations, characterizes the clearly insufficient return of human potential as the main economic resource. Due to the fact that the level of labour productivity in Ukraine is two to three times lower than the potentially achievable, and already achieved in economically advanced countries, in the domestic economy there is insufficient to effectively stimulate labour the level of its payment. This, in turn, not only reduces the interest of workers in productive work, but can also be a cause of social discontent, and this is a threat to social stability, social security.

There is no doubt that the quality of work is influenced by the professionalism of employees, the foundations of which are laid along with the knowledge, skills and abilities in the learning process.

The authors see the threat to economic security in the imperfection of forms, methods, ways of organizing the management of socio-economic development at different levels of the hierarchy, from companies, corporations and ending with state and regional government [16, p. 2265].

In these conditions, higher professional education in Ukraine has a significant responsibility for the training of qualified specialists in the field of management, primarily able to effectively manage socio-economic development at the macroeconomic level.

At present, in the training of management specialists in universities, excessive attention is paid to corporate governance at the microeconomic level, which leads to the study of the basics of production management and personnel management. At the same time, the issues of strategic management, indicative planning, and situational target forecasting at the macroeconomic level are clearly insufficiently studied in terms of volume and content. And this cannot but affect the quality of public economic management and the state of economic security at the sectoral and regional levels, to achieve the goals of state, regional socio-economic programs.

An important element that influences the meaning and influence of activation methods on didactic reality is also the material and technical base of the educational institution, the improvement of which is impossible without the active participation of interested parties (industrial enterprises - stakeholders) through project financing. Thus, higher education institutions that are members of the educational-industrial group receive not only additional extrabudgetary funds, but also a modern material and technical base.

In addition, incubation programs are rapidly developing. Many higher education institutions and enterprises build their survival strategy on the basis of incubation programs and are incubator firms. They provide the most effective assistance to companies by leasing their space to companies. But the most important thing is that students who work in the Business Incubator and are directly involved in both the learning process and the production process, get a positive experience of becoming a professional [17, p. 38].

The most traditional way of interaction is student internship. Accordingly, the problem of organizing the system of interaction of the university with the main bases of practice, with companies where students could perform work according to their profile, needs to be solved. Such a partnership scheme is mutually beneficial, as a firm that admits students to its jobs has the opportunity to see undergraduates working, as companies avoid taking inexperienced graduates directly to the state.

Today, one of the ways to solve the problem of employment of graduates of higher educational institutions is an internship [18, p. 449]. The most modern form of interaction - the formation of endowments (target capital) of leading universities is just taking the form of a bill and is being discussed by the university community. This is one of the innovative forms of cooperation used by leading universities mainly in countries where the state does not fund the higher education system (USA, UK). Endowments are also being introduced into Ukrainian practice: businesses are transferring funds to the university, which, in turn, invests them in stocks or securities and spends the interest on their needs. Thus, the capital of businessmen works for the future, creating a constant supply of the university.

Conclusions. Thus, the above research allows us to draw the following conclusions: the use of properly selected activating methods - the key to success in didactic and educational work; knowledge of each student, his needs and interests will allow to build such structure of classroom activity that the applicant of higher education had an opportunity to reach the purposes and to provide feeling of success; When analysing the variety of methods of conducting classroom classes, the advantages of VLK, a project method of training, which is reduced to the development of a start-up, were identified. In this process, it is important to understand that the world is complex and, accordingly, it is not enough to have one methodology. Keep in mind the strategic management of a start-up, regardless of the size of the temporary organization, management should be simple. Each group / team must choose the most appropriate methodology that best suits the planned business idea. 
The positive impact of education is all the stronger than the great opportunities for adaptation to structural changes in the economy, professional mobility is acquired in the learning process by university graduates. But the system of retraining and advanced training is of paramount importance in preventing the growth of unemployment, ideally supplemented by a planned, pre-planned distribution of graduates. Modern statistics make it possible to trace here the relationship between the amount of retraining and advanced training of workers and changes in unemployment.

It is obvious that education and the financial and economic sphere are connected by many threads, not always noticeable and, as a consequence, are not taken into account when making managerial decisions.

However, there are not so obvious links between education and financial and economic security of the country, which have yet to be identified and studied.

All this must be done in order to have a clear idea of what the national education system should be, which ensures the economic, scientific, technical, social and cultural development of the country at the level of unconditional provision of its national security and socio-economic stability.

\section{References.}

1. Druzhynina, V., Likhonosova, G. and Lutsenko, G. (2018), "Assessment welfare of the population in the synergetic system of socio-economic exclusion", Marketing and Management of Innovations, vol. 2, pp. 54-68.

2. Calinescu, T., Likhonosova, G. and Zelenko, O. (2019), "Digital Economy in Ukraine: Reforms and Development of Business Entities", Proceeding of the 34 International Business Information Management Association Conference (IBIMA), Madrid, Spain, 13-14 November 2019, pp. 2051-2062.

3. Wróblewska, W. "The methods of working with students in the context of the effects specified by the National Qualifications Framework", available at: http://www.e-mentor.edu.pl/artykul/dex/numer/43/id/897 (Accessed on 10.10.2021).

4. Szerląg, A. (2009), "Expectations towards a university graduate as the subject of education", Competencies of university graduates tailored to our times. Selected shots, 36.

5. Pyłka-Gutowska, E. (2008), "Innovative forms and methods of working with students in the field of education for sustainable development", available at: http://www.rceeplock.nazwa.pl/files/rcee/mater_szkol/5_nowatorskie_formy.pdf (Accessed on 10.05.2021).

6. Gryadunova, E., Gorin, A., Gorina, M. and Tokmakov, N. (2018), "The use of innovative teaching methods students of technical specialties", available at: https://cyberleninka.ru/article/n/primenenie-innovatsionnyhmetodov-obucheniya-studentov-tehnicheskih-spetsialnostey/viewer/ (Accessed on 15.06.2021).

7. Chornyi, O., Zagirnyak, M. and Gurzii, A. (2017), Pidvyshchennya yakosti pidhotovky fakhivtsiv na osnovi virtual'nykh laboratornykh kompleksiv [Improved quality of specialists training on the basis of virtual laboratory complexes], Kremenchuk Mykhailo Ostrohradskyi National University, Kremenchuk, Ukraine.

8. Diachenko, A., Manzhula, V. and Popov, A. (2010), Postroyeniye informatsionnykh sistem nepreryvnogo obrazovaniya na osnove internet-tekhnologiy [Building information systems of lifelong education based on Internet technologies], Academy of Natural History, Moscow, Russia.

9. Mateeva Petrova, M. et al. (2018), "Big Data Tools in Processing Information from Open Sources", Proceedings of the 2018 IEEE First International Conference on System Analysis \& Intelligent Computing (SAIC), doi: 10.1109/SAIC.2018.8516800.

10. Strumilin, S. (2004), Otechestvennoye obrazovaniye [Native education], Economic life, Moscow, Russia.

11. Brunetto, Y. and Farr-Wharton, R. (2005), “Academics' Responses to the Implementation of a Quality Agenda", Quality in Higher Education, vol. 11, iss. 2, pp. 14-19.

12. Druzhynina, V., Viedienina, L., Sakun, Yu. and Likhonosova, G. (2020), "Creative analysis of innovation as a catalyser of socialization of structural change", European Journal of Sustainable Development, vol. 9 (2), pp. 349-365.

13. Solovei, O. (2005), Enerhetychnyy audyt [Energy audit], GHDTU, Cherkasy, Ukraine.

14. Kowalczyk, I. (2020), "Start-Up as a Performance of Innovative Entrepreneurship in Poland", Economic, Legal and Administrative Studies, Vol. 1, pp. 63-77.

15. Kulej, A. (2018), "Attributes of startups as innovative business entities, Research Reviews of Czestochowa University of Technology - Management, Vol. 31, pp. 145-153.

16. Calinescu, T., Likhonosova, G. and Zelenko, O. (2019), "Manifestation trend of the behavioural economy in Ukraine by the integration results", Proceeding of the 33 International Business Information Management Association Conference (IBIMA), Granada Spain, 10-11 April 2019, pp. 2264-2273.

17. Druzhynina, V. (2014), Mistsevyy rynok pratsi: umovy funktsionuvannya, metody ta sposoby zabezpechennya zbalansovanosti: monohrafiya [Local labour market: operating conditions, methods and ways to ensure balance: monograph], Yugo-Vostok, Donetsk, Ukraine.

18. Zagirnyak, M., Gladyr, A. and Nozhenko, V. (2020), "Results and Problems of International Academic Exchanges", Proceedings of the 25th IEEE International conference on Problems of automated electric drive. Theory and practice (PAEP2020), pp. 448-451. doi: 10.1109/PAEP49887.2020.9240825. 


\section{Література.}

1. Druzhynina V., Likhonosova G., Lutsenko G. Assessment welfare of the population in the synergetic system of socio-economic exclusion. Marketing and Management of Innovations. 2018. Vol. 2. P. 54-68.

2. Calinescu T., Likhonosova G., Zelenko O. Digital Economy in Ukraine: Reforms and Development of Business Entities. Proceeding of the 34 International Business Information Management Association Conference (IBIMA). 13-14 November 2019. Madrid. Spain. P. 2051-2062.

3. Wróblewska W. The methods of working with students in the context of the effects specified by the National Qualifications Framework. URL: http://www.e-mentor.edu.pl/artykul/dex/numer/43/id/897.

4. Szerląg A. Expectations towards a university graduate as the subject of education. Competencies of university graduates tailored to our times. 2009. Selected shots. 36 .

5. Pyłka-Gutowska E. Nowatorskie formy i metody pracy $\mathrm{z}$ uczniami w zakresie edukacji na rzecz zrównoważonego rozwoju. 2008.

URL:

http://www.rceeplock.nazwa.pl/files/rcee/mater_szkol/5_nowatorskie_formy.pdf.

6. Грядунова Е., Горин А., Горина М., Токмаков Н. Преминение инновационных методов обучения студентов технических специальностей. 2018. URL: https://cyberleninka.ru/article/n/primenenie-innovatsionnyhmetodov-obucheniya-studentov-tehnicheskih-spetsialnostey/viewer/

7. Чорний О. П., Загірняк М. В., Гуржій А. М. та ін. Підвищення якості підготовки фахівців на основі віртуальних лабораторних комплексів : навчальний посібник. Кременчук : КрНУ, 2017. 198 с.

8. Дьяченко А. В., Манжула В. Г., Попов А. Э. Построение информационных систем непрерывного образования на основе интернет-технологий. Москва : Академия Естествознания, 2010. 130 с.

9. Mateeva Petrova, M. et al. Big Data Tools in Processing Information from Open Sources. Proceedings of the 2018 IEEE First International Conference on System Analysis \& Intelligent Computing (SAIC). 2018. doi: 10.1109/SAIC.2018.8516800.

10. Струмилин С. Отечественное образование. Москва : Экономическая жизнь, 2004. 305 с.

11. Brunetto Y., Farr-Wharton R. Academics' Responses to the Implementation of a Quality Agenda. Quality in Higher Education. 2005. Vol. 11. Iss. 2. P. 14-19.

12. Druzhynina V., Viedienina L., Sakun Yu., Likhonosova G. Creative analysis of innovation as a catalyser of socialization of structural change. European Journal of Sustainable Development. 2020. Vol. 9 (2). P. 349-365.

13. Соловей О. Енергетичний аудит. Черкаси : ЧДТУ, 2005. 299 с.

14. Kowalczyk I. Start-Up as a Performance of Innovative Entrepreneurship in Poland. Economic, Legal and Administrative Studies. 2020. Vol. 1. P. 63-77.

15. Kulej A. Attributes of startups as innovative business entities. Research Reviews of Czestochowa University of Technology - Management. 2020. Vol. 31. P. 145-153.

16. Calinescu T., Likhonosova G., Zelenko O. Manifestation trend of the behavioural economy in Ukraine by the integration results. Proceeding of the 33 International Business Information Management Association Conference (IBIMA). 10-11 April 2019. Granada Spain. P. 2264-2273.

17. Дружиніна В. В. Місцевий ринок праці: умови функціонування, методи та способи забезпечення збалансованості : монографія. Донецьк : Юго-Восток, 2014. 366 с.

18. Zagirnyak M., Gladyr A., Nozhenko V. Results and Problems of International Academic Exchanges. Proceedings of the 25th IEEE International conference on Problems of automated electric drive. Theory and practice (PAEP2020). 2020. P. 448-451. doi: 10.1109/PAEP49887.2020.9240825. 